\title{
Outpatient Medical E-Resume in Support INA-CBGs Claims for Covid-19 Patients at Hospital
}

\author{
Fitria Santika $^{1}$, Nurul Azmi Gumanti ${ }^{2}$, Leni Herfiyanti ${ }^{3}$, Candra Mecca Sufyana ${ }^{4}$ \\ Politeknik Piksi Ganesha, Indonesia
}

\section{Article Info}

Article history:

Received August 19, 2021

Revised August 27, 2021

Accepted October 29, 2021

\section{Keywords:}

Medical E-Resume

INA-CBGs

Outpatient

Prototype

Black-box

\begin{abstract}
The lack of information needed to fulfill the claim requirements of Indonesia Case-Based Group (INACBGs) for Coronavirus Diseases (Covid-19) outpatients caused claim disputes, thus hampering the claim process for Covid-19 patients at Hospital. The existence of an electronic medical resume is believed to be a solution and make the claim process more effective. This study aimed to produce an electronic-based outpatient medical resume that fits the needs of Hospital X. The prototype method was chosen because it is suitable for developing systems quickly, and the results are easier to adjust because Hospital X can provide input in the system development process. Based on system testing using the black-box method, the medical e-resume system developed has overcome dispute claims at Hospital.
\end{abstract}

This is an open access article under the CC BY-SA license.

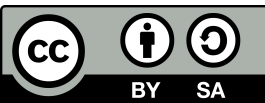

\section{Corresponding Author:}

Fitria Santika,

Informatics Management concentration in Medical Record Informatics,

Politeknik Piksi Ganesha,

Email: fitriasantika08@gmail.com 


\section{INTRODUCTION}

Health facilities, especially hospitals, are essential assets for the community in providing services during emergencies, crises, and disasters and as facilities for the community to regularly check their health. Based on Law No. 44 of 2009 concerning hospitals, the hospital is defined as an institution that provides excellent health services for each individual who provides outpatient, emergency, and inpatient services [1]. Hospitals are a fundamental factor in the development of a health system. The hospital must be satisfactorily managed to provide benefits such as providing easy access for the community, improving patient welfare, and improving the quality of hospital services that impact health services indicators [2]. As time goes by, hospitals have bigger and bigger challenges. One of them is patients who are increasingly knowledgeable and selective in choosing hospitals. Moreover, in this era, the hospital service system has also shifted from a traditional system to a digital system [3]. This situation makes hospitals have to make adjustments by optimizing the quality of service for patients compared to the community's wishes in getting the best service from the hospital according to technological developments.

In order to support health services, there is an essential aspect in the health service section, namely medical records. Medical records are files that contain archives and information regarding patient identities, actions, treatment, examinations, and other services that have been provided to patients in health care facilities [4]. Medical records must be complete and accurate so that they can be accounted for in order to reduce the risk of errors. An incomplete medical resume can affect the quality of a hospital's health services because the medical resume is used as a guide in further treatment for patients. If the medical resume information is incomplete, especially regarding medical history, this can result in the patient's treatment not running continuously [5]. An error occurred because the medical record is a source of health information for patients. It also shows how the services are provided by the hospital to patients.

The National Health Insurance or Jaminan Kesehatan Nasional (JKN) program, driven by the Healthcare and Social Security Agency or Badan Penyelenggara Jaminan Sosial Kesehatan (BPJS), which was implemented on January 1, 2014, is still running today. The Indonesian health care system has transformed the National Health Insurance (JKN) program [6]. BPJS provides health services that cover all health facility providers in the form of Advanced Level Referral Health Facilities or Fasilitas Kesehatan Rujukan Tingkat Lanjutan (FKRTL) and First Level Health Facilities or Fasilitas Kesehtan Tingkat Pertama (FKTP) [7], where the payment system to FKRTL is in the form of Indonesia Case-Based Group's tariffs (INA-CBGs). Payments to FKRTL are made following service packages based on procedures and disease diagnosis groupings [8]. Therefore, the completeness of the contents of the medical record gets to be exceptionally inperative, especially in the outpatient medical resume, because it contains a diagnosis of the patient's disease, which is the basis for determining the diagnosis code of a disease which will later affect the INA-CBGs rates. To comply with the INA-CBGs compliance as regulated in the Minister of Health Regulation No. 40 of 2012 concerning Guidelines for the Implementation of the Public Health Insurance Program, doctors who carry out the treatment are required to write clear and precise diagnoses following the International Classification of Disease (ICD-10) and International Classification of Diseases. (ICD-9) Clinical Modification (CM) [9].

The medical resume of the patient performing the treatment must be filled out and made by the doctor providing the service [3]. In which case, the medical resume must at least contain information regarding the patient's identity, diagnosis, final diagnosis, a summary of the results of supporting and physical examinations, follow-up, and the signature and evident name of the doctor who treated the patient. The completeness of a medical resume is something that is important and affects the hospital. Based on the Decree of the Minister of Health of the Republic of Indonesia No. 129/Menkes/SK/II/2008, the completeness of medical records has a target, namely the completeness of reaching $100 \%$ this is based on the standard of the completeness of medical records of a hospital that has provided services [10]. Permenkes No. 269/Menkes/Per/III/2008 Article 2, Paragraph 1 states that medical records must be complete, precise, written, or made electronically [3].

In the field of education, the role of technology has evolved. Technology has recently become a new phenomenon to motivate, differentiate, and enable achieving and developing in a way that has never been done before [11]. With technological developments dominating at this time, medical resumes are made electronically. The medical resume information system design is designed using the Visual Basic 2010 programming language with Ms. Access. This research was carried out to design an outpatient medical resume information system for Covid-19 patients to support the INA-CBGs claim process in hospitals to minimize the occurrence of dispute claims.

This study is similar to previous studies regarding the design of medical resumes, which were originally done manually and switched to a more modern method by utilizing technology. Previous studies have discussed a lot about the design of an electronic medical resume information system with the aim of providing more effective and efficient services, especially in managing patient data. This research was conducted to complement previous studies with a more specific focus, namely by using the INA-CBGs claim dispute as an example of a problem that can be solved by designing a medical resume information system. Research conducted using specific cases which are rarely found in many previous studies are expected to complete information about the importance of designing a medical resume information system in supporting health services provided by hospitals. This research is discussed

Matrik: Jurnal Managemen,Teknik Informatika, dan Rekayasa Komputer,

Vol. 21, No. 1, November 2021: $87-98$ 
systematically, namely in the introduction section discusses the background of the problems studied, the research methods section discusses the methods used to find solutions to research problems, in the results and analysis section discusses system design and in the conclusion section discusses conclusions and suggestions from the research conducted.

\section{RESEARCH METHOD}

This study was structured using qualitative research methods. This research was conducted from April 4, 2021, to June 4, 2021, at the Medical Record Installation of Hospital X with a focus on research on outpatient medical resumes for Coronavirus Diseases (Covid-19) patients along with other required documents such as triage and lab results for Coronavirus Diseases (Covid-19) patients to support the requirements for BPJS patient claims at the hospital. Qualitative research data collection methods include observation, textual or visual analysis (for example, from books or videos), and individual or group interviews. However, the most commonly used methods, especially in health research, are interviews and group discussions [12]. Data collection methods used in this study are interviews and observations. Collecting data using observation by witnessing directly the activities, whereas the process to obtain information is carried out by conducting questions and answers with related source person [13]. A qualitative approach was implemented to strengthen the data results by conducting in-depth interviews to obtain information. This type of qualitative research aims to identify and analyze data. Qualitative analysis is used for data analysis by describing the results of observations and interviews in the field, especially regarding medical resumes, then determining the leading causes of existing problems and how to fix these problems, and then designing a medical resume information system.

At the design stage, the author uses the prototype development method. The prototype model includes processes, collecting requirements, designing and evaluating prototypes. The following are the processes of developing a prototype development method system.

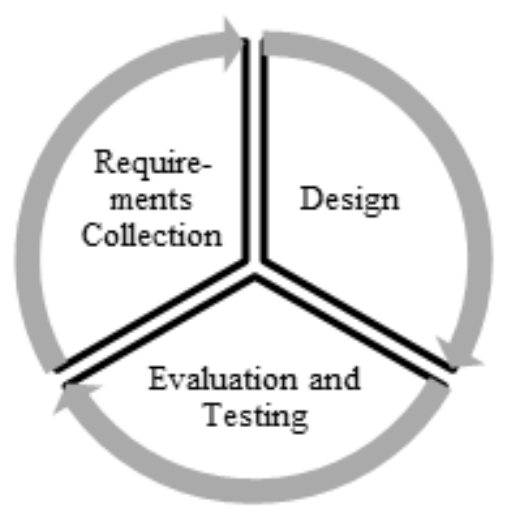

Figure 1. Stages prototype method

\subsection{Requirements Collection}

At the stage of requirements collection, the authors research through observation and interviews. Observation is a qualitative research method that includes participant observation, ethnography, and field research [14]. In this observation, the authors carried out a direct review based on the current system at Hospital X and conducted interviews to find and collect data directly. Based on the results of observations obtained data that 70 out of 140 claim files were disputed. Claim disputes occur due to the incomplete claim file required, such as a medical resume containing detailed patient information that is useful as a condition for claiming INA-CBGs. Lack of information caused hospital staff must attach supporting files such as laboratory and radiology results which should have been listed in the patient's medical resume. So, it is necessary to design a medical e-resume information system to support the INA-CBGs claim process.

\subsection{Design}

The design of this medical resume information system uses Visual Basic programming language and Ms. Access as the database. The resulting designs are: 


\section{Flow map}

Therefore, the author designed a medical resume information system to make it easier to carry out outpatient medical resume claims for Coronavirus Diseases (Covid-19) patients. The Flow map designed is as follows:

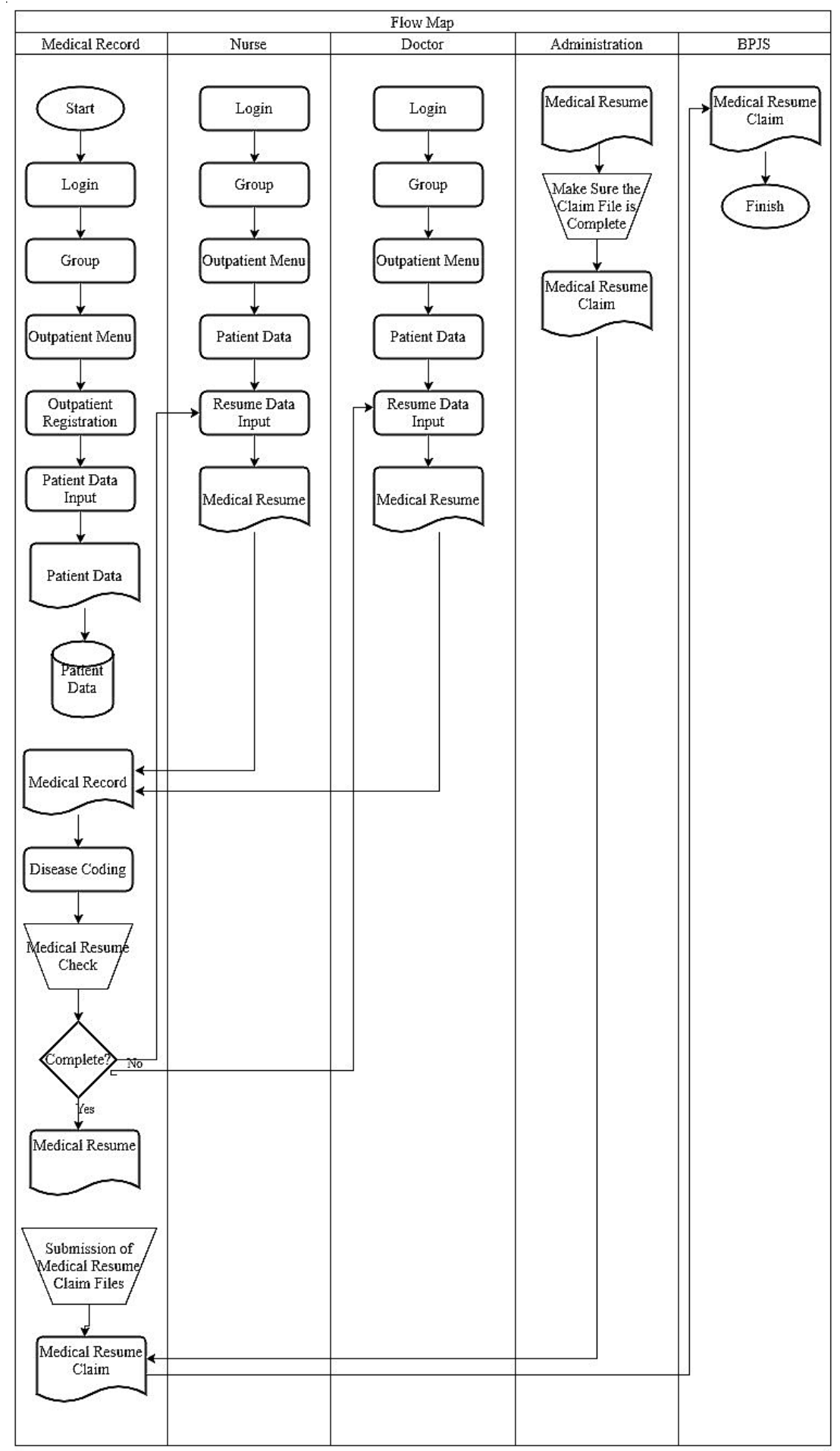

Figure 2. Display system flow map 


\section{Context Diagram}

Context diagram describes the system with external entities that are interconnected. These entities are entities that are directly related to the system. Context diagrams help describe a process that performs the transformation of input data into output data. The following is a context diagram of the design of a medical resume information system design:

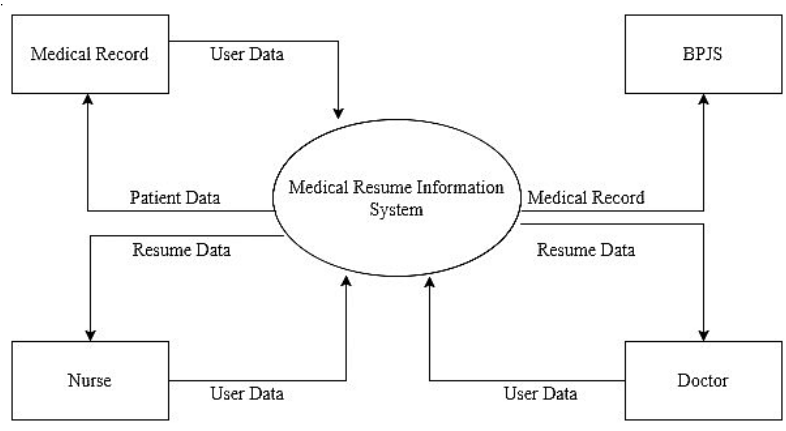

Figure 3. Context Diagram of the designed system

\section{Data Flow Diagram (DFD)}

Data Flow Diagram describes a process of information from input to output. This information flow process is described from the data destination until the data process can be stored. The following is the DFD of the designed system:

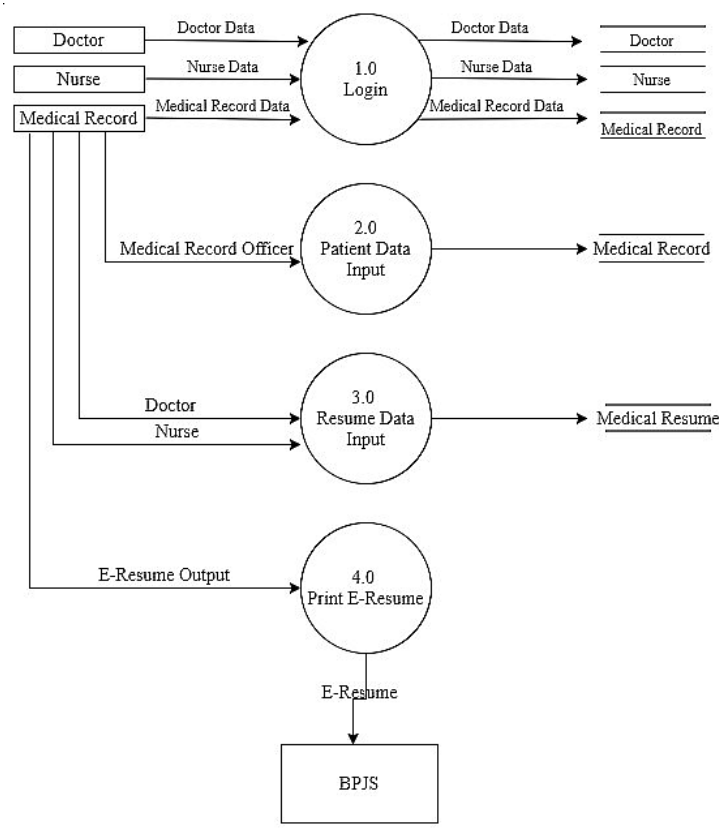

Figure 4. DFD system designed

\section{Database Design}

The Entity Relationship Diagram (ERD) is a graphical representation of the problem domain being modeled. The steps in database design are usually sketching the ER (Entity-Relationships) model [15]. ERD helps database design in identifying data and rules that will be represented and used in the database. 


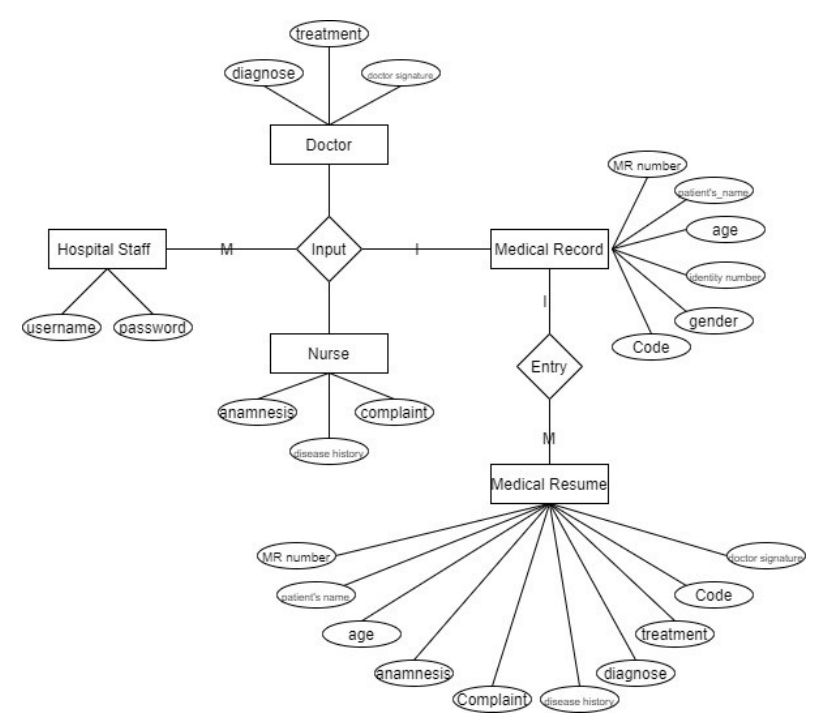

Figure 5. ERD system display

\section{RESULT AND ANALYSIS}

\subsection{Implementation}

The results of this study are the implementation of the interface design of the Medical Resume information system in Supporting the Claims of INA-CBGs for Covid-19 Patients at Hospital X.

\section{Login Menu}

The hospital medical resume application login page shows like the picture underneath; there are fields to fill in the username and password on the login page. Besides that, there are login buttons, cancel buttons, and close buttons. Suppose the user wants to enter the medical resume application system. In that case, they must login first so that the system in the medical resume application can be maintained safely and securely and cannot be used by unauthorized persons.

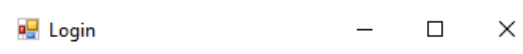

\section{HOSPITAL X}

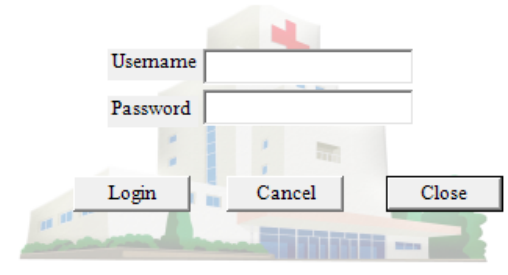

Figure 6. Login display

\section{User Login Page}

The login page for the Hospital medical resume application user has a display according to the image shown below, on this page contains the group and login form. Suppose the user wants to enter the medical resume application system. In that case, they must select a group according to their employment position and then login so that the system in the medical resume application can be maintained safely and securely and cannot be used by unauthorized persons. 

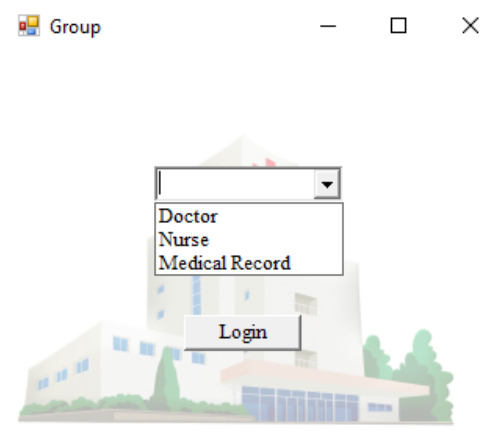

Figure 7. User login page

\section{Main Menu Display}

The main service menu page for the Hospital medical resume application user has a display according to the image shown below, on this page contains several types of services provided, namely emergency care, outpatient, and inpatient services.

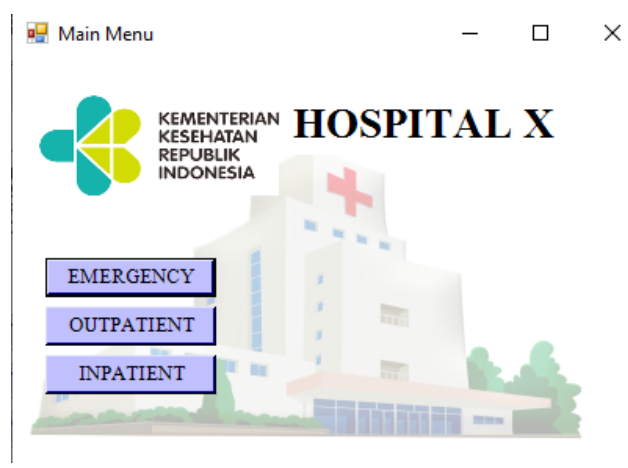

Figure 8. Main menu page

\section{Outpatient Registration Display}

The outpatient registration display for the Hospital medical resume application user displays according to the image shown below. There is a mandatory form on this page to fill in the complete identity of the patient who will register for outpatient services.

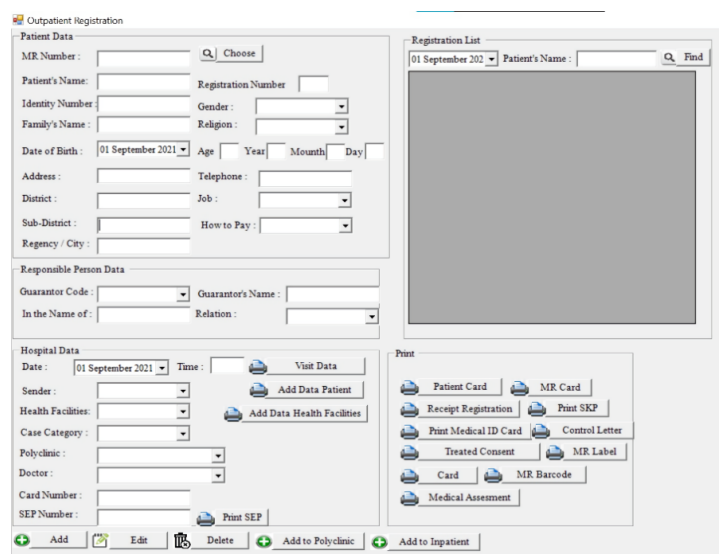

Figure 9. Outpatient registration page 


\section{The Detail Page of the Outpatient}

The details of the outpatient page of the Hospital medical resume application user have a page according to the image shown below; this page contains a toolbar that contains the patient's medical record. After entering the outpatient form, several items will appear containing outpatient details. To create a resume, select the medical resume menu.

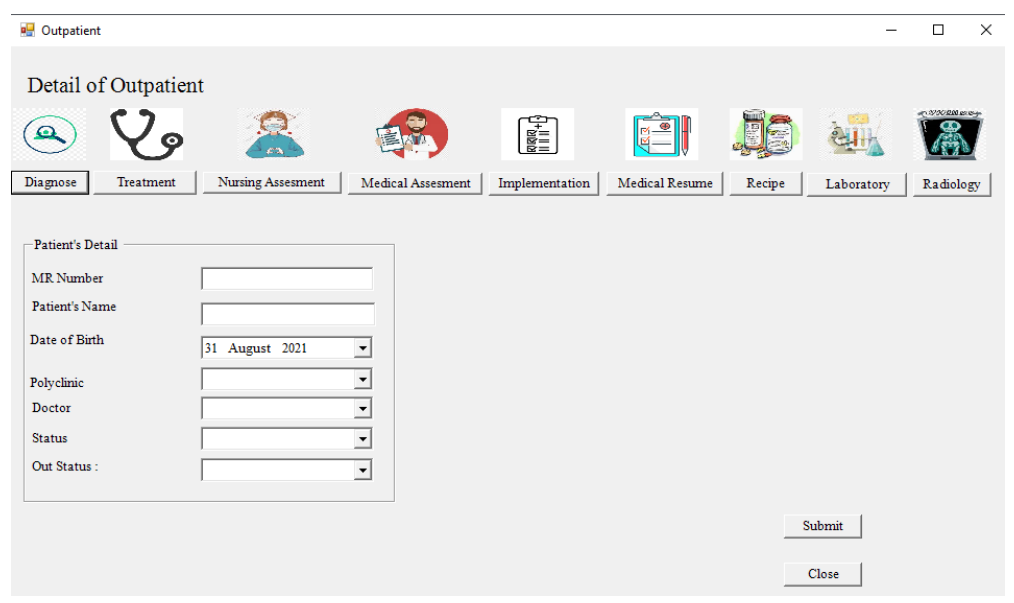

Figure 10. The detail page of the outpatient

\section{Medical Resume Data Input Display}

The medical resume data input display for Hospital medical resume application user has a page according to the image shown below, on this page contains a medical resume data input form filled in by registration officers, doctors, nurses, and coders.

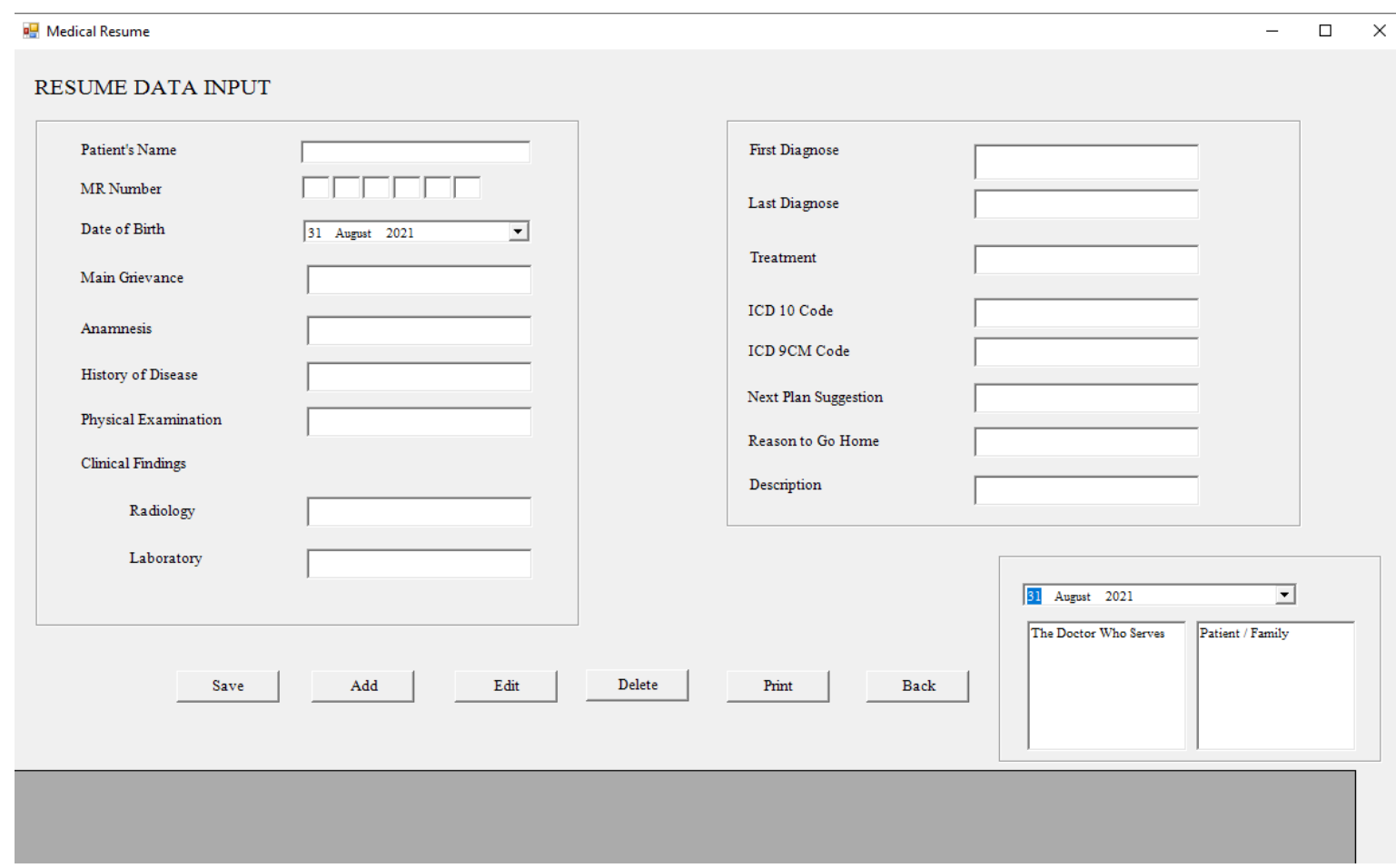

Figure 11. Medical resume data input display

Matrik: Jurnal Managemen,Teknik Informatika, dan Rekayasa Komputer,

Vol. 21, No. 1, November 2021: 87 - 98 


\section{Medical Resume Output}

The output page of the medical resume of users of the Hospital medical resume application has a display according to the image shown below, on this page contains a medical resume that contains data on patients who have performed outpatient services.

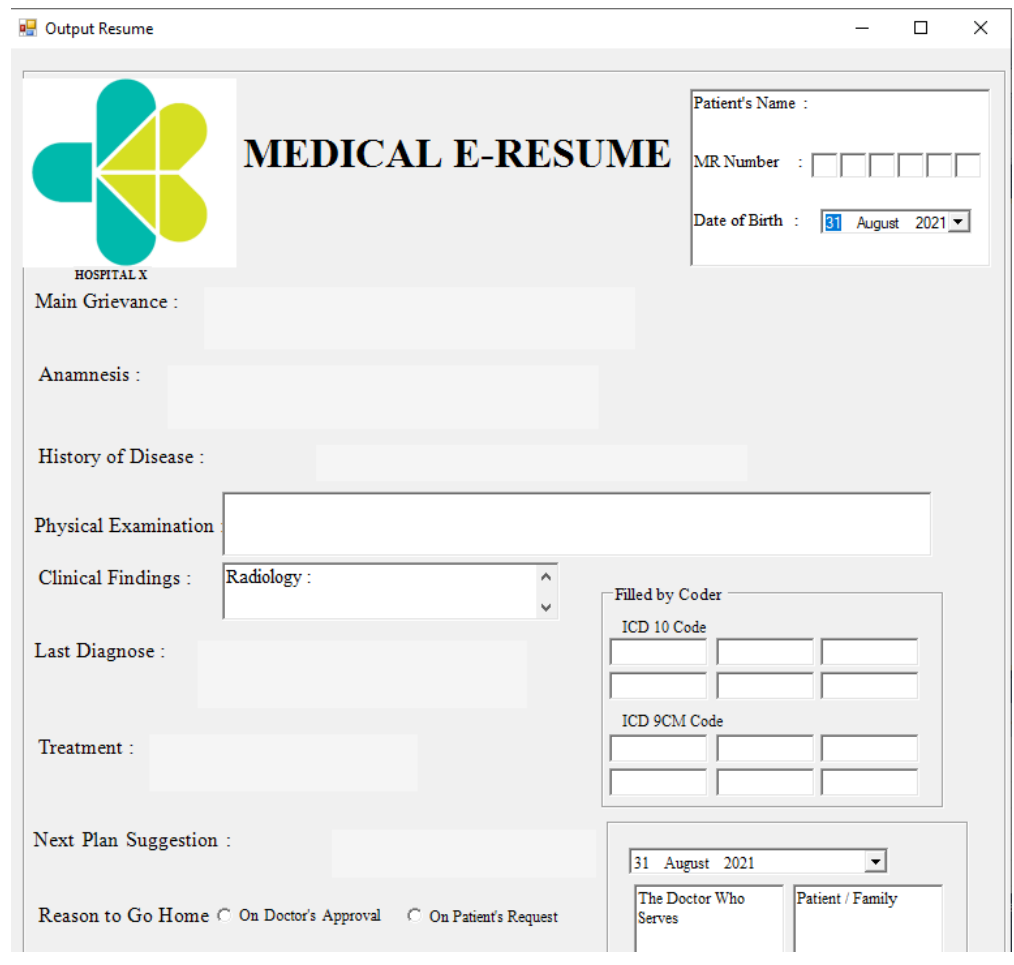

Figure 12. Medical E-Resume output

\section{Prototype Evaluation}

In the design of the medical resume information system made, an evaluation will be carried out to related parties whether the information system created is as expected or not. If inappropriate, it will return to the previous process, collecting requirements and designing, and then re-evaluating. Moreover, if it is appropriate, the medical resume information system that has been evaluated and accepted by the relevant parties is ready to be used.

\section{System Testing using Black box}

Black box testing plays a vital role in software testing. Black box testing is also referred to as functional testing. Functional testing is a technique that is carried out based on information in the specifications so that functions are tested by considering the requirements presented in assisting the validation of the system as a whole [16]. The black box method is carried out to know whether the application is functioning correctly and efficiently or not. After determining the goals and needs, the next step is to design a medical resume to operate appropriately in the implementation phase. After that, evaluate the prototype of the information system design that is made.

The black box method is used to test the system carried out by testing the application detail system such as the interface design display, the functions contained in the system, and the suitability of the function flow on the system that runs through the existing processes hospital. Several things must be considered when testing is carried out, namely when testing is carried out, a good design will easily detect errors, it can speed up the repair process, and of course, can save on testing [17]. 
Table 1. System Test Results Using the Black Box Method

\begin{tabular}{|c|c|c|c|}
\hline Testing Activities & Expected Test Results & Test Activity Results & Decision \\
\hline $\begin{array}{l}\text { User login according to the data } \\
\text { stored in the database. }\end{array}$ & Successfully login. & $\begin{array}{l}\text { Successfully login and a } \\
\text { message appear Login } \\
\text { successfull." If failed to } \\
\text { login, show a message } \\
\text { "Failed to login, please } \\
\text { check your username } \\
\text { and password." }\end{array}$ & Appropriate \\
\hline $\begin{array}{l}\text { Choose a group according to } \\
\text { the position of employment. }\end{array}$ & $\begin{array}{l}\text { Go to the Main Menu } \\
\text { Page. }\end{array}$ & $\begin{array}{l}\text { Successfully entered the } \\
\text { Main Menu Page. }\end{array}$ & Appropriate \\
\hline Choose a Menu of Outpatient menu & $\begin{array}{l}\text { Go to the Outpatient } \\
\text { Registration Page. }\end{array}$ & $\begin{array}{l}\text { Successfully entered the } \\
\text { Outpatient Registration Page. }\end{array}$ & Appropriate \\
\hline $\begin{array}{l}\text { Fill the patient data in the } \\
\text { Outpatient Registration form, } \\
\text { then click the save button. }\end{array}$ & $\begin{array}{l}\text { Patient data was } \\
\text { successfully saved } \\
\text { to the database. }\end{array}$ & $\begin{array}{l}\text { Patient data is successfully } \\
\text { saved to the database, } \\
\text { and a message appears } \\
\text { "Patient data saved to the } \\
\text { database." And then go to } \\
\text { the detail page of the outpatient. }\end{array}$ & Appropriate \\
\hline $\begin{array}{l}\text { Create a Medical Resume by clicking } \\
\text { "Medical Resume" on the outpatient } \\
\text { details/detail page of the outpatient. }\end{array}$ & $\begin{array}{l}\text { Go to the Medical } \\
\text { Resume Data Input } \\
\text { Display }\end{array}$ & $\begin{array}{l}\text { Successfully entered the } \\
\text { Medical Resume Data } \\
\text { Input Display }\end{array}$ & Appropriate \\
\hline $\begin{array}{l}\text { Fill the resume data in the medical } \\
\text { resume data input form, then click } \\
\text { the save button. }\end{array}$ & $\begin{array}{l}\text { Resume data successfully } \\
\text { saved to the database. }\end{array}$ & $\begin{array}{l}\text { Resume data is successfully } \\
\text { saved to the database, and a } \\
\text { message appears "resume } \\
\text { data saved to the database." }\end{array}$ & Appropriate \\
\hline Print E-resume. & E-resume output appears & $\begin{array}{l}\text { E-resume output successfully } \\
\text { appears. }\end{array}$ & Appropriate \\
\hline
\end{tabular}

\section{CONCLUSION}

According to the study results, it can be concluded that the design of an outpatient medical E-resume information system can support the claims of INA-CBGs for Covid-19 patients, including complete patient data that must be listed in supporting documents INA-CBGs claims. The designed medical resume can display complete patient data that has been inputted by medical record officers, doctors, and nurses into the system. This medical resume information system's design can contain all the documents needed in claim requirements without attaching other supporting documents. Based on black-box testing, the system has run as expected, so it is feasible to use in supporting the claims of INA-CBGs for Covid-19 patients at hospital . In conclusion, the medical e-resume information system has been able to meet the needs of hospital. This research was conducted on specific cases that were rarely found in previous studies it is hoped that it can complete information about the importance of designing a medical resume information system in supporting health services provided by hospitals. The results of the medical resume design need to be improved, especially regarding filling out medical resumes that have not been integrated so that they still have to be filled out manually. In further research, it is hoped that this medical resume system can be integrated and can be bridging directly with the INA-CBGs E-Claim application from the ministry of health. 


\section{ACKNOWLEDGEMENTS}

The author would like to thank Hospital X, which has provided opportunities and permits to carry out fieldwork practices and conduct research, LPPM, and the Academic Community of the Politeknik Piksi Ganesha campus, who have supported and provided information related to implementing research.

\section{REFERENCES}

[1] Departemen Kesehatan Republik Indonesia, Pedoman Penyelenggaraan Pelayanan Rumah Sakit. Jakarta: Kementrian Kesehatan RI, 2010.

[2] C. A. Araujo, M. M. Siqueira, and A. M. Malik, "Hospital Accreditation Impact on Healthcare Quality Dimensions: A Systematic Review," International Journal for Quality in Health Care, vol. 32, no. 8, pp. 531-544, 2020.

[3] K. Marzuki, A. Apriani, and N. G. A. Dasriani, "Pemberdayaan Pengrajin Perak Melalui Market Place sebagai Media Penjualan Online di Desa Ungga, Kabupaten Lombok Tengah,” ADMA : Jurnal Pengabdian dan Pemberdayaan Masyarakat, vol. 1, no. 2, pp. 107-114, 2021.

[4] Permenkes, "Peraturan Menteri Kesehatan Republik Indonesia Nomor: 269/MENKES/PER/III/2008 Tentang Rekam Medis," Jakarta, p. 7, 2008.

[5] I. Suhartina, "Analisis Kuantitatif Ketidaklengkapan Pengisian Resume Medis Berdasarkan Program Quality Assurance (Suatu Studi di Rumah Sakit Delta Surya Sidoarjo),” Jurnal Kesehatan Vokasional, vol. 4, no. 2, p. 80, 2019.

[6] W. P. Nugraheni, A. H. Zahroh, and R. K. Hartono, "Best Practice of Hospital Management Strategy To Thrive in The National Health Insurance (Jkn) Era,” Jurnal Administrasi Kesehatan Indonesia, vol. 9, no. 1, p. 9, 2021.

[7] Permenkes, "Permenkes No. 52 Tahun 2016 Tentang Standar Tarif Pelayanan Kesehatan dalam Penyelenggaraan Program Jaminan Kesehatan,” Jakarta, p. 31, 2016.

[8] —_ "Permenkes No. 27 Tahun 2014 Tentang Petunjuk Teknis Sistem Indonesian Case Base Groups (INA-CBGs)," Jakarta, p. 3, 2007.

[9] —_ "Peraturan Menteri Kesehatan Republik Indonesia Nomor 40 Tahun 2012,” Jakarta, p. 58, 2012.

[10] Kepmenkes, "Menteri Kesehatan Republik Indonesia Nomor: 129/Menkes/SK/II/2008 Tentang Standar Pelayanan Minimal Rumah Sakit," Jakarta, p. 55, 2008.

[11] J. L. Harris, M. T. Al-Bataineh, and A. Al-Bataineh, "One to One Technology and its Effect on Student Academic Achievement and Motivation," Contemporary Educational Technology, vol. 7, no. 4, pp. 368-381, 2020.

[12] I. A. Ismail, "Understanding Quantitative and Qualitative Research Methods : A Theoretical Perspective for Young Researchers Understanding Quantitativeand Qualitative Research Methods : A Theoretical Perspective for Young Researchers," no. February, pp. 70-87, 2021.

[13] K. Marzuki, A. , and L. Z. Azhar mardedi, "Evaluasi Penerapan Teknologi Informasi E-Learning pada Kampus Swasta Menggunakan Cobit 4.1 (Study Kasus Prodi Ilkom Universitas Bumigora)," Jurnal Bumigora Information Technology (BITe), vol. 1, no. 2, pp. 161-166, 2019.

[14] L. Busetto, W. Wick, and C. Gumbinger, "How to Use and Assess Qualitative Research Methods," Neurological Research and Practice, vol. 2, no. 1, pp. 1-10, 2020.

[15] R. Rashkovits and I. Lavy, "Mapping Common Errors in Entity Relationship Diagram Design of Novice Designers," International Journal of Database Management Systems, vol. 13, no. 1, pp. 1-19, 2021.

[16] D. Bonetti, "Systematic Literature Review of Software Testing in Healthcare Evaluation of Educational Games for Computing Education View project," 2021.

[17] B. A. Priyaungga, D. B. Aji, M. Syahroni, N. T. S. Aji, and A. Saifudin, "Pengujian Black Box pada Aplikasi Perpustakaan Menggunakan Teknik Equivalence Partitions,” Jurnal Teknologi Sistem Informasi dan Aplikasi, vol. 3, no. 3, p. 150, 2020. 
